\title{
Nutritional value and safety of air potato Dioscorea bulbifera L. fermented with Pleurotus ostreatus and Calocybe indica
}

\section{Tolulope Bolaniran ${ }^{1}$, Clement Olusola Ogidi $^{1,2, *}$ and Bamidele Juliet Akinyele ${ }^{1}$}

${ }^{1}$ Department of Microbiology. The Federal University of Technology. PMB 704 Akure. Nigeria.*Email: clementogidi@yahoo.com.

${ }^{2}$ Biotechnology Unit. Department of Biological Sciences. Kings University. PMB 555 Odeomu. Nigeria.

\begin{abstract}
The proximate, minerals, antinutrient and amino acid contents of the unfermented air potato (UAP), fermented air potato (APF), fermented air potato with Pleurotus ostreatus (APP) and fermented air potato with Calocybe indica (APC) were carried out using standard methods. The biosafety of the samples was also determined using Wistar rats. APP has the highest crude fiber (11.61\%) and protein content (20.44\%). APF has the highest moisture content of $12.95 \%$, while UAP has the highest carbohydrate content of $71.46 \%$. The mineral composition $(\mathrm{mg} / \mathrm{g})$ of samples revealed that APP has the highest $\mathrm{Zn}(1.21), \mathrm{Fe}(7.53)$ and $\mathrm{Mn}(0.78 \%)$. APC has the highest Ca (71.31\%), $\mathrm{Mg}$ (4.76) and $\mathrm{K}(60.65)$, while APF has the highest $\mathrm{Cu}(1.72 \%)$, Ni (0.38\%), Cr (0.65\%), Cd (0.29) and $\mathrm{Pb}(25.16)$. Unfermented air potato (UAP) contains the highest amount of phenols, tannin and saponin with the values of $1.16 \mathrm{mg} / \mathrm{g}, 2.50$ $\mathrm{mg} / \mathrm{g}$ and $2.57 \mathrm{mg} / \mathrm{g}$, respectively. APP has the highest flavonoid $(2.77 \mathrm{mg} / \mathrm{g})$ and alkaloids (3.05 mg/g) and significantly different $(p<0.05)$ from other samples. Essential and non-essential amino acid detected in unfermented and fermented air potato ranged from 0.70 to $10.81 \mathrm{mg} / \mathrm{g}$. Hematological and histopathological studies revealed no adverse effect on the blood and organs of the rats. The fungal mycelia enhanced the nutritional contents of fermented air potato. Hence, bioactive compounds in air potato can be of exploited and supplemented into food products.
\end{abstract}

Keywords: Food security; Fermentation; Detoxification; Food nutrients.
Received

April 24, 2019

Accepted

August 30, 2019

Released

August 31, 2019

Full Text Article

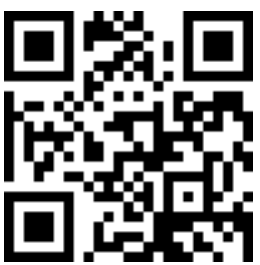

\footnotetext{
ORCID

(ㄱ) 0000-0002-5347-2058 Tolulope Bolaniran

(ㄷ) 0000-0002-4144-6750 Clement Olusola Ogidi

(D) 0000-0003-1684-987X Bamidele Juliet Akinyele
} 


\section{Introduction}

Food nutrients are essential for human to maintain physiological balance, healthy growth, reproduction, and prevention of chronic diseases (Whitney and Rolfes, 2013). Bioavailability of nutrients in fermented foods, edible fungi and other herb products has eliminated some health-threatening aliments like obesity, metabolic syndromes, cardiovascular disease, diabetes, and osteoporosis (Willett, 2006; Ferreira et al., 2017). People are often undernourished when food intake falls below minimum requirement as a result of unavailability of food, which resulted to energy and nutrient deficiencies. Food insecurity has however posed serious challenges in many countries as a result of increased in the world population (Allen, 2011; Godfray et al., 2014). Researchers are looking for ways to solve the problem of food insecurity by focusing on proper utilization of crops that have been abandoned or not commonly eaten due to the pre-knowledge from parents to offspring about the crops or prolong time of cooking.

Air potato Dioscorea bulbifera, a true yam species commonly found in Africa, Southern Asia and Northern Australia, is one of the abandoned food crops, which had been used to treat various ailments such as ulcers, sores, wound, spasms, dysentery and diabetes due to its unique bioactive components (Shriram et al., 2008). This yam species is not popular and is not usually eaten, unlike the common yams that are often consume in many places (Igyor et al., 2004). Despite the nutritional composition and some health benefits recorded about air potato, many still have the ancient or traditional believe and assumed it cannot be consumed, and therefore neglected by most people (Afiukwa and Igwe, 2015).
One of the major food processing methods is fermentation, which detoxifies food substrates, enhance its nutritive value, prolong shelf life, and sensory quality of food and reducing the cooking time. Solid state fermentation, is a lower moisture medium that allow growth of microbes especially yeast and mould on solid substrate, fungi often involved as agent of fermentation, to improve the production of secondary metabolites after breaking down of complex molecules (Han 2003). It has been found that a few microorganisms Candida tropicalis, Torulopsis candida, Aspergillus flavus and Aspergilus niger are capable of degrading gossypol in food substrates (Weng and Sun, 2006; Khalaf and Meleigy, 2008). Aquiahuatl et al. (1998) established that caffeine can be removed from coffee infusions as well as synthetic growth media by Aspergillus, Penicillium and Trichoderma strains by solid state fermentation. This improved the nutritional value of coffee pulp for animal feed. Paecilomyces variotii has been reported to be an excellent tannindegrading microorganism as a tannase producer (Battestin and Macedo, 2007).

It is therefore, expected that fungi can be used to degrade the toxic compound in air potato by solid state fermentation, in order to enhance its nutritive values and increase its food potential as functional foods, thereby making it more acceptable to the public. Air potato is eaten only in some rural areas and is generally underutilized for both commercial and subsistence uses. The full potential of this yam species is still not known hence, there is need for further and extensive research on it. This study was designed to evaluate the nutrient composition and biosafety of unfermented and fermented air potato with Pleurotus ostreatus and Calocybe indica. 


\section{Materials and methods}

\section{Collection of air potato bulbils}

Air Potato bulbils were collected from a farm in Ore, Ondo state. It was authenticated in The Department of Crop, Soil and Pest, The Federal University of Technology, Akure (FUTA).

\section{Source of fungi}

Spawn of Pleurotus ostreatus and Calocybe indica were collected from FIIRO, Lagos. Pure cultures of Pleurotus ostreatus and Calocybe indica were isolated by cultivating them on sterile PDA and incubated at $25 \pm 2{ }^{\circ} \mathrm{C}$ for 7 days in an incubator.

\section{Sample preparation}

The bulbils were peeled and cut into smaller sizes. It was divided into four portions; the first sample $(250 \mathrm{~g})$ was sun-dried at room temperature for 7 days and milled to powder labelled as unfermented air potato (UAP). The second portion, $250 \mathrm{~g}$ was subjected to submerged fermentation for 5 days, thereafter, it was sun-dried, milled and labelled as fermented air potato (APF). The third and fourth samples 250 g each of peeled bulbils were solidly fermented with Pleurotus ostreatus or Calocybe indica mycelium according to the modified method of Li et al. (2013). Briefly, this fermentation was carried out by growing the mycelia in a well sterilized $\left(121^{\circ} \mathrm{C}\right.$ for $\left.15 \mathrm{~min}\right)$ PDA broth, these mycelia was allowed to grow for
5 days then poured into container containing the air potato bulbils and left to grow in a dark place at $25 \pm 2{ }^{\circ} \mathrm{C}$ for 7 days. The fermented samples were sundried, milled and labelled as air potato fermented with Pleurotus ostreatus (APP) and air potato fermented with Calocybe indica (APC).

\section{Proximate analysis of unfermented and fermented air potato bulbils}

The proximate analysis of the samples for moisture, ash, crude fibre, protein, fat and carbohydrate were carried out according to the standard methods as recommended by AOAC (2016). Briefly, the moisture content was determined by drying $2 \mathrm{~g}$ of each sample an oven (Leniscope, England) at $105^{\circ} \mathrm{C}$ for $48 \mathrm{~h}$. Ash content of unfermented and fermented was determined by ashing 2.0 g of each sample in a muffle furnace (Lenton Furnaces, England) at $600{ }^{\circ} \mathrm{C}$ for $3 \mathrm{~h}$. Crude fibre was determined by acid and alkaline digestion methods with $20 \%$ $\mathrm{H}_{2} \mathrm{SO}_{4}$ and $\mathrm{NaOH}$ solution. The fat content was determined by extracting fat from $2 \mathrm{~g}$ of each sample using n-hexane in Soxhlet extractor. The solvent evaporated and passed through the sides tube of the extract to the reflux condenser. Kjeldahl distillation apparatus was used to determine nitrogen content $(\mathrm{N})$ of each sample, which multiplied by 6.25 . Total carbohydrates was determined by the formula stated below:

Total carbohydrates $=100-\%($ protein + ash + crude fibre + fat + moisture contents $)$

\section{Mineral unfermented and fermented air potato bulbils}

The minerals of the samples were analyzed using the method of AOAC (2016). Minerals were analyzed by digesting dry ashing $\left(600{ }^{\circ} \mathrm{C}\right)$ of unfermented and fermented air potato bulbils and dissolved it in $\mathrm{HCl}(25 \mathrm{~mL})$ and $5 \%$ lanthanum chloride $(2 \mathrm{~mL})$, boiling, filtering and making up to standard volume with deionized water. Mineral viz $\mathrm{Zn}, \mathrm{Fe}, \mathrm{Cu}, \mathrm{Ca}, \mathrm{Mg}, \mathrm{Ni}, \mathrm{Cr}, \mathrm{Cd}$, $\mathrm{Mn}$, and $\mathrm{Pb}$ were determined with atomic absorption spectrometer (Buck Scientific, Model 200A/200, Inc. East Norwalk, Connecticut, USA) with their appropriate wavelength. A flame photometer was used to determine $\mathrm{Na}$ and $\mathrm{K}$ in the samples. 


\section{Antinutrient analysis of unfermented and fermented air potato bulbils}

Chemical tests for the screening and identification of bioactive chemical constituents in the raw and fermented samples under study were carried out using the standard procedures for alkaloids, tannins, saponins, phenols and flavonoids as described by Trease et al. (2002), Banso and Adeyemo (2007), and Obadoni and Ochuko (2001).

\section{Determination of amino acid of unfermented and fermented air potato bulbils}

Method of AOAC (2016) was used in the extraction of the sample for the amino acid analysis. About $5 \mathrm{~g}$ of the sample was weighed into the $250 \mathrm{~mL}$ conical flask capacity. The sample was defatted by extracting the fat content of the sample with $30 \mathrm{~mL}$ of the petroleum ether three times with Soxhlet extractor that was equipped with a thimble. Then the sample was hydrolysed, evaporated in a rotary evaporator and loaded into Applied Biosystems PTH Amino Acid Analyzer.

Determination of amino acid content of cultivated Pleurotus spp.

The amino acid profile of Pleurotus spp. was determined using the method described by Benitez (1989). Four stages were involved in the determination of the amino acid content of Pleurotus spp. Five grams (5 g) of the samples were dried to constant weight, defatted, hydrolysed.

Experimental design to assess the biosafety of unfermented and fermented air potato bulbils

The male and female Wistar rats for the experiment were obtained from the Department of Animal Production and Health, The Federal University of Technology, Akure. The animals have an initial weight of 60-62 g. They were kept in an animal house under standard environmental condition and were acclimatized for seven days due to the change of environment. They were fed grower's mash for the period of acclimatization before grouping them for the biosafety test. Four rats were assigned into each group and labelled as follow:

CC: rats fed basal diet;

BUAP: rats fed unfermented air potato;

BAPF: rats fed fermented air potato;

BAPP: rats fed air potato fermented with Pleurotus ostreatus; and

BAPC: rats fed air potato fermented with Calocybe indica.

\section{Biosafety procedure}

The biosafety of the unfermented and fermented samples was also determined by feeding Wistar rats with $15 \mathrm{~g}$ of each samples for 14 days. Wistar rats fed basal diet served as the control. This was done to know if the consumption of these samples would have negative effect on the internal organs of the animals (Olatoye and Arueya, 2018).

\section{Collection of blood samples \\ Anaesthetization \\ method} described by Cheesbrough (2000) was used with slight modification in the collection of the blood samples. The blood samples collected were tested for Red Blood Cell counts (RBC), White Blood Cell counts (WBC), Haemoglobin (Hb) concentration, Erythrocyte Sedimentation Rate (ESR) and Packed Cell Volume (PCV) according to the method described by Baker et al. (1998).

\section{Histopathological examination}

Liver and kidneys were preserved in $10 \%$ neutral buffered formalin solution for $24 \mathrm{~h}$ and washed with $70 \%$ ethanol. Tissues were then placed in small metal caskets, stirred by a magnetic stirrer, dehydrated using alcohol series from $70 \%$ to $100 \%$ alcohol and embedded in paraffin using an embedding machine. Paraffin blocks 
were sectioned using a rotary ultramicrotome, distributed onto glass slides and then dried overnight. Slides were observed under a light microscope after being stained with hematoxylin and eosin (H\&E) dyes and mounted according to standard method of Baker et al. (1998).

\section{Statistical analysis}

Data obtained from the experiments was subjected to One Way Analysis of Variance (ANOVA). Means were separated using Duncan's New Multiple Range Test at 95\% confidence level using Statistical Packages for the Social Sciences (SPSS) version 17.0, differences between means was considered significant at $\mathrm{P} \leq 0.05$.

\section{Results}

\section{Proximate and mineral composition of unfermented and fermented air potato}

The proximate composition of unfermented air potato (UAP), fermented air potato (APF), fermented air potato with Pleurotus ostreatus (APP), and fermented air potato with Calocybe indica (APC) expressed in percentage as shown in Table 1 . It was observed that the unfermented air potato (UAP) has the highest carbohydrate content of $71.46 \%$. Fermented air potato (APF) has the highest moisture content of $12.95 \%$, while air potato fermented with Calocybe indica (APC) has the highest ash content with value of $3.87 \%$. Air potato fermented with Pleurotus ostreatus (APP) showed the highest crude fibre and protein contents of $10.51 \%$ and $20.44 \%$, respectively.

The mineral composition $(\mathrm{mg} / \mathrm{kg})$ of unfermented and fermented air potato are shown in Table 2 . Unfermented air potato (UAP) contained the highest sodium content of 4.525 $\mathrm{mg} / \mathrm{kg}$ but was reduced $(\mathrm{p}<0.05)$ in fermented air potato (APF), APC and APP as $27.25 \mathrm{mg} / \mathrm{kg}, 23.44 \mathrm{mg} / \mathrm{kg}$ and 21.54 $\mathrm{mg} / \mathrm{kg}$. Air potato fermented with Pleurotus ostreatus (APP) contained the highest $(\mathrm{p}<0.05)$ zinc and iron content of $1.21 \mathrm{mg} / \mathrm{kg}$ and $7.53 \mathrm{mg} / \mathrm{kg}$, respectively, while air potato fermented with Calocybe indica (APC) has the highest magnesium content of 4.76 $\mathrm{mg} / \mathrm{kg}$ when compared to other samples. Potassium content $(59.74 \mathrm{mg} / \mathrm{kg}$ ) and $(60.95 \mathrm{mg} / \mathrm{kg})$ in air potato fermented with Pleurotus ostreatus (APP) or Calocybe indica (APC) are also significantly different from others.

Table 1. Proximate composition of unfermented and fermented air potato.

\begin{tabular}{lcccc}
\hline Proximate & UAP (\%) & APF (\%) & APP (\%) & APC (\%) \\
\hline Moisture & $9.18^{\mathrm{c}} \pm 0.02$ & $12.5^{\mathrm{d}} \pm 0.03$ & $6.57^{\mathrm{a}} \pm 0.02$ & $6.73^{\mathrm{b}} \pm 0.21$ \\
Ash & $1.26^{\mathrm{a}} \pm 0.03$ & $2.47^{\mathrm{b}} \pm 0.02$ & $3.67^{\mathrm{c}} \pm 0.04$ & $3.87^{\mathrm{d}} \pm 0.03$ \\
Protein & $15.48^{\mathrm{b}} \pm 0.02$ & $7.66^{\mathrm{a}} \pm 0.03$ & $20.44^{\mathrm{d}} \pm 0.03$ & $19.85^{\mathrm{c}} \pm 0.04$ \\
Crude fibre & $2.34^{\mathrm{a}} \pm 0.05$ & $7.66^{\mathrm{b}} \pm 0.05$ & $10.51^{\mathrm{d}} \pm 0.03$ & $8.36^{\mathrm{c}} \pm 0.05$ \\
Fat & $0.49^{\mathrm{b}} \pm 0.03$ & $0.55^{\mathrm{c}} \pm 0.05$ & $0.23^{\mathrm{a}} \pm 0.05$ & $0.73^{\mathrm{d}} \pm 0.05$ \\
Carbohydrates & $71.25^{\mathrm{d}} \pm 0.04$ & $68.71^{\mathrm{c}} \pm 0.02$ & $58.58^{\mathrm{a}} \pm 0.01$ & $60.46^{\mathrm{b}} \pm 0.03$ \\
\hline
\end{tabular}

Values are means \pm SE of replicates $(n=3)$. Values in the same row with the same superscript letter are not significantly different at $\mathrm{p} \leq 0.05$ using Duncan's new multiple range test. UAP: Unfermented air potato, $\mathrm{APF}=$ Fermented air potato, $\mathrm{APP}=$ Air potato fermented with Pleurotus ostreatus, APC = Air potato fermented with Calocybe indica. 
Table 2. Mineral composition of unfermented and fermented air potato.

\begin{tabular}{|c|c|c|c|c|c|c|c|c|c|c|c|c|}
\hline Sample & $\mathrm{Zn}$ & $\mathrm{Fe}$ & $\mathrm{Cu}$ & $\mathrm{Ca}$ & $\mathrm{Mg}$ & $\mathrm{Ni}$ & $\mathrm{Cr}$ & Cd & $\mathrm{Mn}$ & $\mathrm{Pb}$ & $\mathrm{Na}$ & $\mathrm{K}$ \\
\hline UAP & $1.02^{b} \pm 0.00$ & $2.53^{b} \pm 0.02$ & $0.25^{b} \pm 0.01$ & $65.52^{b} \pm 0.03$ & $2.53^{\mathrm{a}} \pm 0.02$ & $0.00^{\mathrm{a}} \pm 0.00$ & $0.05^{\mathrm{a}} \pm 0.03$ & $0.00^{\mathrm{a}} \pm 0.00$ & $0.52^{\mathrm{a}} \pm 0.01$ & $0.02^{\mathrm{a}} \pm 0.01$ & $47.25^{b} \pm 0.05$ & $33.85^{b} \pm 0.05$ \\
\hline APF & $0.25 \mathrm{a} \pm 0.00$ & $0.71^{\mathrm{a}} \pm 0.00$ & $1.72^{\varsigma} \pm 0.01$ & $30.68 \mathrm{a} \pm 0.00$ & $3.99^{b} \pm 0.01$ & $0.38^{c} \pm 0.02$ & $0.65^{\mathrm{a}} \pm 0.01$ & $0.29^{a} \pm 0.05$ & $1.60^{c} \pm 0.00$ & $25.16^{d} \pm 0.04$ & $27.25^{\mathrm{a}} \pm 0.04$ & $30.76^{\mathrm{a}} \pm 0.02$ \\
\hline APP & $1.21^{d} \pm 0.00$ & $53^{d} \pm 0.01$ & $0.25 \mathrm{a} \pm 0.01$ & $.51^{b} \pm 0.01$ & $.38^{c} \pm 0.02$ & $28^{b} \pm 0.03$ & $0.08^{b} \pm 0.01$ & $0.01 \mathrm{a} \pm 0.00$ & $0.78^{b} \pm 0.01$ & $0.09^{b} \pm 0.01$ & $21.54^{c} \pm 0.04$ & $59.74^{\circ} \pm 0.15$ \\
\hline APC & $1.06 \pm 0.00$ & $6.98^{\circ} \pm 0.01$ & $0.26^{b} \pm 0.01$ & $71.31^{`} \pm 0.01$ & $4.76^{d} \pm 0.04$ & $0.27^{b} \pm 0.02$ & $0.06^{\mathrm{a}} \pm 0.02$ & $0.01^{\mathrm{a}} \pm 0.00$ & $0.53^{\mathrm{a}} \pm 0.01$ & $0.15^{c} \pm 0.04$ & $23.44^{d} \pm 0.05$ & $60.95^{c_{+}+0.05}$ \\
\hline
\end{tabular}

Values are means \pm SE of replicates $(n=3)$. Values in the same column carrying the same superscript are not significantly different at $(\mathrm{p} \leq 0.05)$ using Duncan's New Multiple Range test. $\mathrm{UAP}=$ Unfermented air potato, $\mathrm{APF}=$ Fermented air potato, APP $=$ Air potato fermented with Pleurotus ostreatus, APC= Air potato fermented with Calocybe indica.

\section{Antinutrient constituents of raw and fermented samples}

Table 3 shows phytochemicals in unfermented and fermented air potato. The unfermented air potato (UAP) has the highest phenol $(1.16 \mathrm{mg} / \mathrm{g})$, tannins $(2.50 \mathrm{mg} / \mathrm{g})$, and saponins $(2.57 \mathrm{mg} / \mathrm{g})$. Air potato fermented with Pleurotus ostreatus (APP) has the highest ( $\mathrm{p}<0.05$ ) flavonoids of $2.77 \mathrm{mg} / \mathrm{g}$ and alkaloids of
$3.05 \mathrm{mg} / \mathrm{g}$ and significantly different from other samples. Air potato fermented with Calocybe indica (APC) has the lowest saponins of $0.31 \mathrm{mg} / \mathrm{g}$, air potato fermented Pleurotus ostreatus (APP) has the lowest tannins of 0.09 $\mathrm{mg} / \mathrm{g}$, fermented air potato (APF) has the lowest phenol content of $0.02 \mathrm{mg} / \mathrm{g}$. Tannin was found absent in air potato that undergone submerge fermentation.

Table 3. Quantitative phytochemicals $(\mathrm{mg} / \mathrm{g})$ in unfermented and fermented air potato.

\begin{tabular}{lcccc}
\hline Phytochemical & UAP & APF & APP & APC \\
\hline Phenols & $1.16^{\mathrm{c}} \pm 0.04$ & $0.02^{\mathrm{a}} \pm 0.01$ & $0.35^{\mathrm{b}} \pm 0.04$ & $0.39^{\mathrm{b}} \pm 0.01$ \\
Tannins & $2.50^{\mathrm{b} \pm 0.01}$ & 0.0 & $0.09^{\mathrm{a}} \pm 0.01$ & $0.14^{\mathrm{a}} \pm 0.01$ \\
Alkaloids & $0.96^{\mathrm{a}} \pm 0.03$ & $0.96^{\mathrm{a}} \pm 0.04$ & $3.05^{\mathrm{c}} \pm 0.04$ & $2.26^{\mathrm{b}} \pm 0.05$ \\
Flavonoids & $1.56^{\mathrm{a}} \pm 0.03$ & $2.75^{\mathrm{b}} \pm 0.04$ & $2.77^{\mathrm{b}} \pm 0.03$ & $2.70^{\mathrm{b}} \pm 0.01$ \\
Saponins & $3.57^{\mathrm{d}} \pm 0.02$ & $1.74^{\mathrm{c}} \pm 0.04$ & $0.41^{\mathrm{b}} \pm 0.02$ & $0.31^{\mathrm{a}} \pm 0.01$ \\
\hline
\end{tabular}

Values are means \pm SE of replicates $(n=3)$. Values in the same row carrying the same superscript are not significantly different at ( $\mathrm{p} \leq 0.05$ ) using Duncan's New Multiple Range test. UAP = Unfermented air potato, APF = Fermented air potato, APP= Air potato fermented with Pleurotus ostreatus, APC = Air potato fermented with Calocybe indica.

The amino acids of unfermented air potato, fermented air potato, air potato fermented with Calocybe indica, and air potato fermented with Pleurotus ostreatus was revealed in Table 4. It was observed that the following essential amino acids: leucine, threonine, lysine, isoleucine, phenylalanine, histidine, valine, methionine, tryptophan were present in studied samples. Leucine was the highest with a value of $9.45 \mathrm{mg} / \mathrm{g}$. Non-essential amino acid such as serine, alanine, aspartic acid, and glutamic acid were present in varying concentrations ranging from 4.63 to $10.81 \mathrm{mg} / \mathrm{g}$.

$$
\text { Hematological parameters }
$$

obtained from the rat fed unfermented and fermented air potato was reported in Table 5. The packed cell volume (PCV) of the animal ranged from 21.00 to $33.33 \%$, with the rat fed fermented air potato (BAPF) possessed the lowest PCV of $21.00 \%$, while the rat fed unfermented air potato (BUAP) have the highest PCV of $33.33 \%$. The haemoglobin (HB) of rat fed basal diet (CC), rat fed air potato 
fermented with Pleurotus (BAPP), and rat fed air potato fermented with Calocybe (BAPC) with values of $7.01 \%, 9.47 \%$, $9.47 \%$ are significantly different from BUAP (11.40\%) and BAPF (22.17\%). The white blood cell (WBC) of rats ranged from 3.97 to 5.20 with BAPF having the lowest WBC and BAPC having the highest WBC of $5.20 \%$. The red blood cell (RBC) ranged from 2.66 to $4.04 \%$.

Table 6 shows the mean differential count of rats tested for biosafety of unfermented and fermented air potato. The lymphocytes ranged from 55.03 to $58.33 \%$. The highest value was recorded in rat fed air potato fermented with Pleurotus (BAPP). The neutrophils ranged from 32.67 to $40.66 \%$ with the rat fed air potato fermented with Calocybe (BAPC) have the highest value. The eosinophils ranged from 1.00 to $3.00 \%$. Rat fed air potato fermented with Calocybe for biosafety (BAPC). The monocytes ranged from 1.00 to $2.00 \%$. The basophils have no value across all the experimental rats.

Table 4. Amino acids (mg/g) of unfermented and fermented air potato.

\begin{tabular}{|c|c|c|c|c|}
\hline Amino Acid & UAP & APF & APP & APC \\
\hline Leucine & $6.40^{\mathrm{a}} \pm 0.46$ & $5.81^{\mathrm{a}} \pm 0.24$ & $9.45^{c} \pm 0.41$ & $8.60^{b} \pm 0.43$ \\
\hline Lysine & $3.04^{\mathrm{a}} \pm 0.17$ & $2.81^{\mathrm{a} \pm 0.24}$ & $4.60^{\mathrm{b}} \pm 0.51$ & $4.50^{\mathrm{b}} \pm 0.50$ \\
\hline Isoleucine & $2.47^{\mathrm{a}} \pm 0.53$ & $2.50^{\mathrm{a} \pm 0.44}$ & $7.70^{\mathrm{b}} \pm 0.30$ & $7.47^{b} \pm 0.46$ \\
\hline Phenylalanine & $3.71^{\mathrm{a} \pm 0.32}$ & $3.66^{\mathrm{a}} \pm 0.49$ & $5.65^{c} \pm 0.51$ & $4.73^{b} \pm 0.24$ \\
\hline Tryptophan & $0.73^{a} \pm 0.23$ & $0.82^{\mathrm{a}} \pm 0.17$ & $1.17 \mathrm{a} \pm 0.29$ & $1.34^{\mathrm{a} \pm 0.55}$ \\
\hline Valine & $3.78^{a} \pm 0.29$ & $3.57 \mathrm{a} \pm 0.48$ & $5.49^{b} \pm 0.43$ & $5.27^{b} \pm 0.56$ \\
\hline Methionine & $0.97^{a} \pm 0.15$ & $0.79^{\mathrm{a}} \pm 0.17$ & $1.21^{\mathrm{ab}} \pm 0.23$ & $1.51^{b} \pm 0.34$ \\
\hline Proline & $2.53^{\mathrm{a}} \pm 0.44$ & $2.56^{\mathrm{a}} \pm 0.49$ & $2.88^{a} \pm 0.38$ & $2.79^{a} \pm 0.33$ \\
\hline Tyrosine & $2.24^{\mathrm{a}} \pm 0.37$ & $2.16^{\mathrm{a} \pm 0.45}$ & $3.43^{\mathrm{b}} \pm 0.34$ & $2.97 \mathrm{~b} \pm 0.08$ \\
\hline Histidine & $1.61^{\mathrm{a}} \pm 0.08$ & $1.50^{\mathrm{a}} \pm 0.13$ & $2.62^{\mathrm{b}} \pm 0.20$ & $2.60^{\mathrm{b}} \pm 0.33$ \\
\hline Cystine & $0.71^{\mathrm{a}} \pm 0.13$ & $0.70^{\mathrm{a}} \pm 0.24$ & $1.28^{\mathrm{a}} \pm 0.58$ & $0.95^{\mathrm{a} \pm 0.05}$ \\
\hline Alanine & $3.56^{b} \pm 0.48$ & $2.26^{\mathrm{a}} \pm 0.23$ & $4.84^{c} \pm 0.25$ & $4.58^{c} \pm 0.37$ \\
\hline Glutamic acid & $6.95^{b} \pm 0.10$ & $5.57 \mathrm{a} \pm 0.51$ & $10.81^{d} \pm 0.32$ & $9.44^{c} \pm 0.39$ \\
\hline Glycine & $3.42^{\mathrm{a}} \pm 0.45$ & $3.59^{\mathrm{ab}} \pm 0.59$ & $5.63^{c} \pm 0.50$ & $4.43^{b} \pm 0.38$ \\
\hline Threonine & $2.76^{\mathrm{a}} \pm 0.32$ & $2.53^{\mathrm{a}} \pm 0.31$ & $3.38^{\mathrm{b}} \pm 0.21$ & $3.40^{\mathrm{b}} \pm 0.22$ \\
\hline Serine & $3.44^{\mathrm{a}} \pm 0.44$ & $3.63^{\mathrm{a}} \pm 0.48$ & $4.63^{b} \pm 0.55$ & $4.55^{b} \pm 0.44$ \\
\hline Aspartic acid & $5.54^{\mathrm{a}} \pm 0.50$ & $4.87^{b} \pm 0.11$ & $8.65^{\mathrm{d}} \pm 0.26$ & $7.94^{c} \pm 0.50$ \\
\hline
\end{tabular}

Values are means \pm SE of replicates $(n=3)$. Values in the same row carrying the same superscript are not significantly different at ( $\mathrm{p} \leq 0.05)$ using Duncan's New Multiple Range test. UAP = Unfermented air potato, APF $=$ Fermented air potato, APP = Air potato fermented with Pleurotus ostreatus, APC = Air potato fermented with Calocybe indica.

Table 5. Hematological parameter of rat tested for biosafety.

\begin{tabular}{lcccc} 
Sample & PCV (\%) & HB (\%) & WBC $\left(\mathbf{m m}^{\mathbf{3}}\right)$ & $\mathbf{R B C}^{\left(\mathbf{m m}^{3}\right)}$ \\
\hline CC & $31.33 \pm 3.45^{\mathrm{b}}$ & $7.01 \pm 0.78^{\mathrm{a}}$ & $3.54 \pm 0.78^{\mathrm{a}}$ & $2.89 \pm 0.87^{\mathrm{a}}$ \\
BUAP & $33.33 \pm 4.16^{\mathrm{b}}$ & $11.40 \pm 1.31^{\mathrm{b}}$ & $4.90 \pm 0.70^{\mathrm{b}}$ & $4.04 \pm 0.17^{\mathrm{b}}$ \\
BAPF & $21.00 \pm 3.00^{\mathrm{a}}$ & $22.17 \pm 0.56^{\mathrm{c}}$ & $3.97 \pm 0.60^{\mathrm{a}}$ & $2.66 \pm 0.57^{\mathrm{a}}$ \\
BAPP & $32.33 \pm 2.52^{\mathrm{b}}$ & $9.47 \pm 0.50^{\mathrm{a}}$ & $4.30 \pm 0.53^{\mathrm{ab}}$ & $3.07 \pm 0.22^{\mathrm{a}}$ \\
BAPC & $31.00 \pm 3.60^{\mathrm{b}}$ & $9.47 \pm 0.50^{\mathrm{a}}$ & $5.20 \pm 0.44^{\mathrm{bc}}$ & $3.07 \pm 0.23^{\mathrm{a}}$ \\
\hline
\end{tabular}

Values are means \pm SE of replicates $(n=3)$. Values in the same column carrying the same superscript are not significantly different at $(\mathrm{p} \leq 0.05)$ using Duncan's New Multiple Range test. CC-rats fed with basal diet, BUAP- rats fed unfermented air potato, BAPF- rats fed fermented air potato, BAPP- rats fed air potato fermented with Pleurotus, BAPC - rats fed air potato fermented with Calocybe, PCV = Packed cell volume, $\mathrm{HB}=$ Haemoglobin, $\mathrm{WBC}=$ White blood cell, $\mathrm{RBC}=$ Red blood cell. 
Table 6. Differential count (\%) of rats tested for biosafety.

\begin{tabular}{lcccc}
\hline Samples* & Lymphocytes & Neutrophils & Eosinophils & Monocytes \\
\hline CC & $55.03 \pm 3.98^{\mathrm{a}}$ & $35.00 \pm 1.08^{\mathrm{a}}$ & $1.00 \pm 0.00^{\mathrm{a}}$ & $1.00 \pm 0.00^{\mathrm{a}}$ \\
BUAP & $56.33 \pm 6.03^{\mathrm{a}}$ & $35.67 \pm 3.51^{\mathrm{ab}}$ & $1.00 \pm 0.00^{\mathrm{a}}$ & $1.00 \pm 0.00^{\mathrm{a}}$ \\
BAPF & $56.66 \pm 3.05^{\mathrm{a}}$ & $32.67 \pm 3.06^{\mathrm{a}}$ & $2.00 \pm 0.00^{\mathrm{b}}$ & $2.00 \pm 0.00^{\mathrm{b}}$ \\
BAPP & $58.33 \pm 1.52^{\mathrm{a}}$ & $35.00 \pm 3.61^{\mathrm{ab}}$ & $3.00 \pm 0.00^{\mathrm{c}}$ & $1.00 \pm 0.00^{\mathrm{a}}$ \\
BAPC & $56.00 \pm 2.00^{\mathrm{a}}$ & $40.66 \pm 3.98^{\mathrm{b}}$ & $3.00 \pm 0.00^{\mathrm{c}}$ & $1.00 \pm 0.00^{\mathrm{a}}$ \\
\hline
\end{tabular}

Values are means \pm SE of replicates $(n=3)$. Values in the same column carrying the same superscript are not significantly different at $(p \leq 0.05)$ using Duncan's New Multiple Range test. CC rats fed with basal diet, BUAP - rats fed unfermented air potato, BAPF - rats fed fermented air potato, BAPP- rats fed air potato fermented with Pleurotus, BAPC - rats fed air potato fermented with Calocybe. *Basophils were very minimal in all the experimental rats.

\section{Photomicrograph of the kidney of experimental albino rats fed with the samples for biosafety}

Histopathological assay of the vital organs of the experimental rats showed different pathological features (Figures 1 and 2). The kidney of experimental albino rat fed unfermented air potato (BUAP) showed the presence of renal cortex, revealing a minor disturbance in the glomerular frame work (A). The kidneys of experimental albino rats fed fermented air potato (BAPF), air potato fermented with Pleurotus ostreatus (BAPP) or air potato fermented with Calocybe indica (BAPC) showed minor disturbance in the glomerular frame work as in $\mathrm{B}, \mathrm{C}$ and $\mathrm{D}$, respectively.

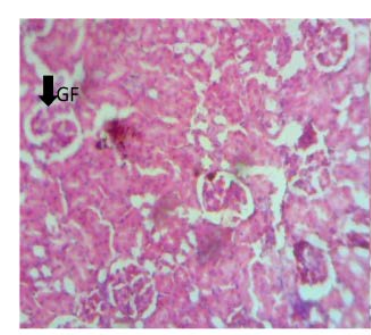

A

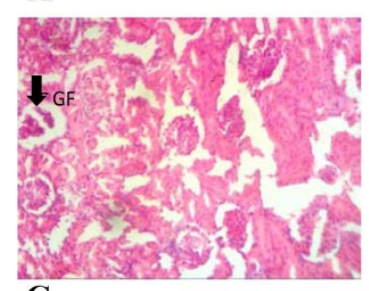

C

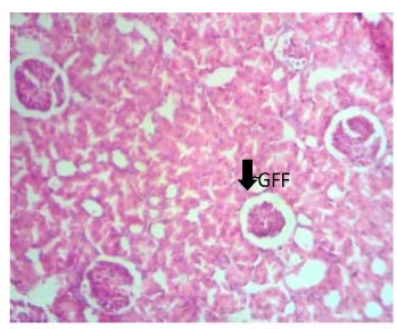

B

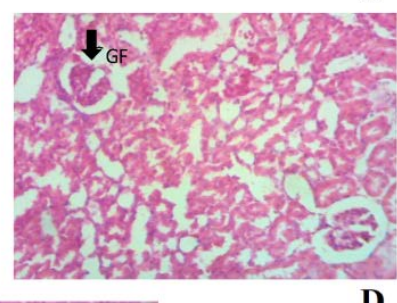

D

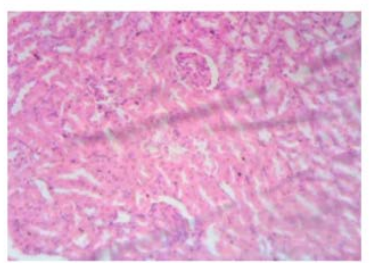

E

Figure 1. Photomicrograph of kidney of albino rat fed (A) unfermented air potato (BUAP), (B) fermented air potato (BAPF), (C) air potato fermented with Pleurotus ostreatus (BAPP), (D) air potato fermented with Calocybe indica (BAPC) and (E) Basal diet (CC). GF: minor disturbance of glomerular framework. 
The livers of experimental albino rats fed unfermented air potato (BUAP), air potato fermented with Pleurotus ostreatus (BAPP) and air potato fermented with Calocybe indica (BAPC) showed normal hepatic cells indicated in $\mathrm{F}, \mathrm{G}$ and $\mathrm{H}$ respectively. The liver of the experimental albino rats fed with fermented air potato (BAPF) showed minor karyolysis (K) of the liver cells (I)

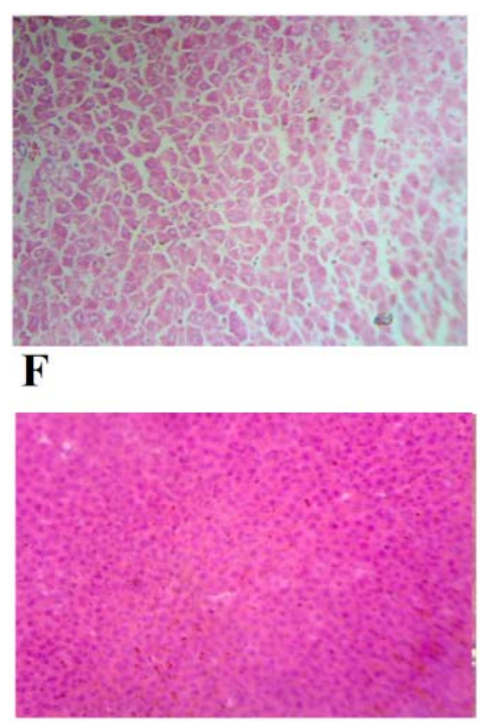

$\mathbf{H}$

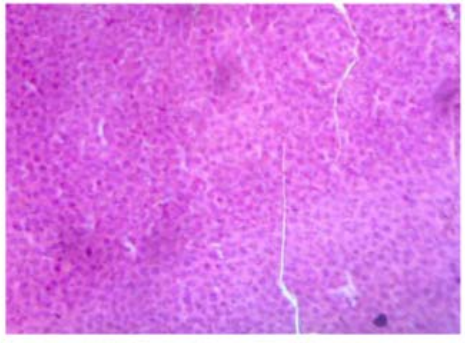

G

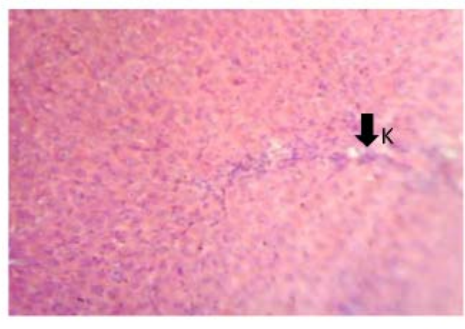

I

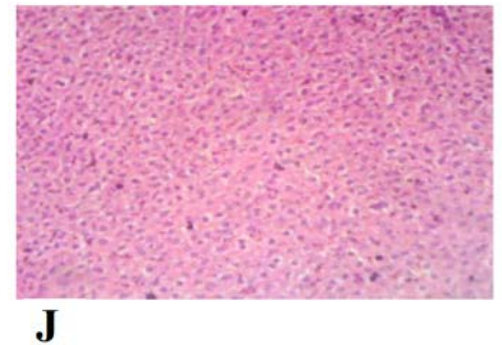

Figure 2. Photomicrograph of liver of rat (F) fed unfermented air potato (BUAP), (G) fed air potato fermented with Pleurotus ostreatus (BAPP), (H) fed air potato fermented with Calocybe indica (BAPC), (I) fed fermented air potato (BAPF) and (J) fed basal diet (CC). K: minor karyolysis.

\section{Discussion}

The study revealed the nutrient contents of unfermented and fermented air potato bulbils with edible fungal mycelia. The high value of carbohydrates recorded for unfermented air potato agreed with the findings of Abara et al. (2003) who suggested that yam can serve as a potential source of energy to humans. Relatively low level of carbohydrates was obtained in air potato fermented with Pleurotus ostreatus and Calocybe indica. This may be as the result of breaking down of the hydrocarbon bonds in the sugar molecules by lignocellulose- degrading enzymes, particularly the panel of ligninolytic enzymes in the fungal mycelium (Stamets, 2000). This could make it find application in production of food products for diabetics and hypertensive patients that required low sugar diet. 
The protein content of unfermented air potato showed higher value than those documented in the reports of Abara et al. (2003), and Igyor et al. (2004). The higher protein recorded in this study suggested that air potato might be a good source of dietary proteins. However, the protein contents of air potato fermented with Pleurotus ostreatus and Calocybe indica increased significantly $(\mathrm{p}<0.05)$ when compared to unfermented). The higher protein content in fermented samples can be attributed to the effect of fungi during solid-state fermentation. This agreed with Han (2003) who stated that food substrate fermented with Pleurotus enrygii during solid-state techniques improve the production of secondary metabolites, which invariably increase the protein content of the food. The increase in nutritional contents of final products after solid- state fermentation could be as a result of the low level of free water, which enable the fungal mycelia to grow without hindrance on the bulbils, thereby breaking down complex organic compounds and releasing secondary metabolites.

Air potato fermented with Pleurotus ostreatus and Calocybe indica have low fat content, which could prolong its shelf life and other food products formulated from it. Hence, it could be exploited as a functional food for patients suffering from atherosclerosis or related aliments (Alissa and Fern, (2002). The moderate crude fibre composition of air potato fermented with Pleurotus ostreatus and Calocybe indica could signify its potential usefulness in food supplementation. Crude fibre is essential in the control of oxidative processes in food products and functional food ingredient (Mandalari et al., 2010).

Significant increment in crude fibre of fermented air potato could be exploited for human uses. Crude fibre played a physiological role of in the body by maintaining proper peristaltic movement of the intestinal tract (Ahmad et al., 2013). A low diet in fibre could lead to constipation, which might bring discomfort to the body system with running stool (Ahmad et al., 2013). Air potato fermented with Pleurotus ostreatus flour can be exploited and supplemented into food to control obesity, since diet with high fibre and reduced fat contents can be used to control weight and obesity, as they give a sense of satiety even when small food is eaten (Ekpo and Onigbinde, 2005).

The moderately low moisture content of air potato flour fermented with Pleurotus ostreatus and Calocybe indica would enhance its shelf life characteristics and prevent chances of microbial deterioration of foods. High moisture content of flour usually predisposes foods to high prevalence of microbial attack unless properly dried (Eleazu et al., 2013). The ash content of air potato fermented with Pleurotus ostreatus and Calocybe indica are higher than the unfermented air potato. It has been observed that ash content of a given foods correlate with the mineral contents of the foods (Ahmad et al., 2013). Hence, our findings revealed that air potato fermented with Pleurotus ostreatus and Calocybe indica flour are high in minerals and could improve mineral intake to suppress the symptom of mineral deficiencies.

This study revealed that air potato fermented with Pleurotus ostreatus and Calocybe indica contain high abundance of calcium, sodium, potassium iron, zinc and magnesium, which suggest it could therefore serve as dietary source of essential elements to improve mineral intake. Utilization of fermented air potato with fungi will go a long way to reduce malnutrition and calcium deficiency that have contributed to health challenges, especially osteoporosis and blood clotting (Vasanthi et al., 2010).

Air potato fermented with fungi had the higher amino acid contents. The bulbils fermented with Pleurotus ostreatus have the highest values, which 
suggest Pleurotus ostreatus was more capable of utilizing organic molecules in the bulbils and was able to release more secondary metabolites. Pleurotus ostreatus could be useful to the sustainable functional food since they possess an increased protein content with valuable essential amino acids that can be exploited to meet the human requirement for growth and health balance (Lavelli et al., 2018).

Aspartic and glutamic acids are non-essential amino acids found in significant quantities, this is of importance, since most of the dispensable amino acids derive their amino groups from glutamic acid which, in turn has ketoglutaric acid and ammonia as its precursor, equally aspartic acid is a precursor of such essential amino acid as isoleucine, methionine, threonine and lysine (Stryer, 1997). The significance of air potato fermented with edible fungi to health cannot be over stated, considering the levels of essential and non-essential amino acid contents found in this yam species. This yam species contains all the nine essential amino acids the body cannot synthesized, which are required to play various roles in the body; valine helps to stimulate muscle growth and energy production (Alozie et al., 2009)), threonine is a principal part of structural proteins, fat metabolism and immune function (Kubala, 2018). Tryptophan is a neurotransmitter that regulates appetite, sleep and mood, methionine plays an important role in metabolism and detoxification and also helps in the absorption of zinc and selenium, minerals that are vital to health (Mbome et al.,1995), leucine helps to regulate blood sugars levels, stimulate wound healing and produces growth hormones, isoleucine helps in immune function, hemoglobin production and energy regulation and histidine is a neurotransmitter that is vital to immune response, digestion, sleep-wake cycle and serves as protective barrier surrounding the nerve cells (Kubala,
2018). Essential amino acids are at the core of many vital processes in our body, which must be provided from our diets. Hence, this yam species has all the essential amino acids, which can be enhanced by fermentation with edible fungi.

The phytochemicals in air potato; both fermented and unfermented revealed that saponins, flavonoids, alkaloids, phenols and tannins were present in various quantities. Though, tannin was absent in air potato fermented using submerged fermentation, which might have been washed down from the bulbils into water. This agreed with Chung et al. (1998) who stated that tannin in many plant foods are water-soluble polyphenols. Fermented air potato with Pleurotus ostreatus and Calocybe indica possessed reduction in tannins, saponin and phenols. The higher content of tannins in unfermented air potato could be the reason why it was neglected. Tannins in food products inhibit the activities of trypsin, chemotrypsin, amylase and lipase, decrease the protein quality of foods and interfere with dietary iron absorption (Eleazu et al., 2013), Saponins, another phytochemical that was highly present in raw air potato. Saponins, in high concentrations impart a bitter taste and astringency in dietary plants Habtamu and Ratta, 2014). The bitter taste of saponin could be the major factor that limits consumption of air potato. Saponins were recognized as antinutrient constituents due to their adverse effects such as growth impairment and therefore, reduced food intake due to the bitterness and throatirritation. (Okwu, 2004).

Phenol was highly present in raw sample, it has been traditionally considered as antinutritive compounds due to the adverse effect of one of their main components. Though, all these phytochemicals have their own health benefits depending on their concentration in food. Air potato fermented with Pleurotus ostreatus and 
Calocybe indica show low level of these phytochemicals: taninins, saponin and phenol, which suggest fungi can reduce antinutrient in plant, thereby making this yam species safe and useful as a functional food. Fungi were able to increase the flavonoids content, which has been recorded to have extensive biological properties that promote human health and help reduce the risk of diseases ((Kumar and Pandey, 2013). As a dietary component, flavonoids are thought to have health-promoting properties due to their high antioxidant capacity both in vivo and in vitro systems (Cook and Samman, 1996). Flavonoids have ability to induce human protective enzyme systems. The number of studies has suggested protective effects of flavonoids against many infectious (bacterial and viral diseases) and degenerative diseases such as cardiovascular diseases, cancers, and other age-related diseases (Kumar et al., 2013). Alkaloids, phytochemical present in fermented samples, had been reported to be one of the most efficient therapeutic phytochemicals in plants (Cordell et al., 2001).

Many researchers had shown that fungi can grow and degrade various toxic compounds by the action of various enzymes found in fungi (Majcherczyk et al., 1998, Nyanhongo et al., 2006). Pleurotus ostreatus has been shown to have a high biodegradation activity (Baldrian et al. 2000). This ability has generally been attributed to the lignindegrading enzyme system; laccase and manganese peroxidase (Baldrian et al. 2000; Kubátová et al., 2001). Luz et al. (2014) revealed that antinutrient composition; phorbol esters found in Jatropha seed cake can be degraded by $P$. ostreatus and found the final products useful as animal feed. Motomura et al (2003) reported that Pleurotus ostreatus can be used to degrade aflatoxin in food, Furthermore, $P$. ostreatus has been shown to degrade a wide variety of phenolic compounds including those that are inhibitory to Saccharomyces cerevisiae (Giardini et al., 2010).

Fermented edible food crops and their derivatives have been shown to have many bioactive components and to give many health benefits but the safety of the foods cannot be neglected ed. Therefore, fermented foods need to be further examined to ensure it is safe, free from microbes and toxic substance before prescription for acceptance, consumption and or used for other applications (Gan et al., 2017). For this course, biosafety analysis of unfermented and fermented air potato revealed no death of animal recorded throughout the experimental duration. The rats fed unfermented and fermented flours showed no sign of weakness or illness, the results of the hematological test showed that the unfermented and fermented flours have no significant effects on the packed cell volume, white blood cells, and hemoglobin. The blood cell parameters were very close to expected normal range reported by Olatoye and Arueya, (2018). There were no significant differences between differential count parameters of rats fed with experimental diet and those not fed with the diet. This is a positive immunomodulatory potential. Finding of Princewill-Ogbonna et al. (2015) reported similar results, hence, it reflects the potential health benefits of yam species.

There were no significant pathological changes in liver and kidney of rats fed unfermented and fermented air potato. These results were in agreement with the report of Olatoye and Arueya (2018) who stated the hepatocytes in the liver showed no form of necrosis or lesions and any histopathological alterations and distortions. They appeared physically normal and healthy. Findings from this study revealed that rats fed air potato fermented with Pleurotus ostreatus and Calocybe indica shows normal histopathological parameters within the 
days of treatment period, this suggest it can be exploited and used to feed animal until after clinical trials to gain wide acceptance in order to tackle food insecurity.

\section{Conclusion}

Pleurotus ostreatus and Calocybe indica can be used to enhance the nutritive value and degrade or breakdown down toxic organic compounds in air potato thereby making it more acceptable to the public and can be exploited to develop functional food as a means of health promoting strategy as well as solving the problem of food insecurity. This study also showed that air potato is not as poisonous as people believed since the unfermented air potato has no adverse effect on the kidney and liver of the rats. This negate the traditional believe of most people about the yam species. Further research needs to be carried out on this yam species to know how it can be exploited and fortified to other food of low diets.

\section{Conflict of interest}

Authors declare that that there is no conflict of interest.

\section{References}

Abara, A. E.; Udosen, E. O.; Eka, O. U. Moisture content and polyphenol oxidase activity of growing Dioscorea bulbifera as indicators of tuber maturation. Global Journal of Pure Applied Science, v. 9, no. 1, p. 113-116, 2003.

Afiukwa, C.; Igwe, D. Comparative nutritional and phytochemical evaluation of the aerial and underground tubers of air potato (Dioscorea bulbifera). British Journal of Applied Science \& Technology, v. 11, no. 4, p. 1-7, 2015. https://doi.org/10.9734/ BJAST/2015/20249

Ahmad, S. M.; Birnin-Yauri, U. A.; Bagudo, B. U.; Sahabi, D. M. Comparative analysis on the nutritional values of crayfish and some insects. African Journal of Food Science and Technology, v. 4, no. 1, p. 9-12, 2013.

Alisa, E. M.; Ferns, G. A. Functional foods and nutraceuticals in the primary prevention of cardiovascular diseases. Journal of Nutrition and Metabolism, v. 2012, Article ID 569486, 2012. https://doi.org/10.1155/ 2012/569486

Allen, M. Food security: Background, issues and challenges. Research and Information Service Briefing Paper, 113/11, 2011. Available from: <http://www.niassembly. gov.uk/globalassets/documents/raise/public ations/2011/agriculture-and-ruraldevelopment/13311.pdf>. Accessed on: Apr. 23, 2019.

Alozie, Y.; Akpanabiatu, M. I.; Eyong, E. U.; Umoh, I. B.; Alozie, G. Amino acid composition of Dioscorea dumetorum varieties. Pakistan Journal of Nutrition, v. 8, no. 2, p. 103-105, 2009.

AOAC-Association of Official Analytical Chemists. Official methods of analysis. 20. ed. Arlington: AOAC, 2016.

Aquiahuatl, M. A.; Raimbault, M.; Roussos, S.; Trejo, M. R. Coffee pulp detoxification by solid state fermentation: Isolation, identification and physiological studies. In: Raimbault, M. (Ed.). Solid state fermentation in bioconversion of agroindustrial raw materials. Montpellier: ORSTOM, 1988. p. 13-26. (Proceedings of the Seminar Solid state fermentation in bioconversion of agro-industrial raw materials). Available from: <http://www.documentation.ird.fr/hor/fdi:3 0607>. Accessed on: Apr. 23, 2019.

Baker, F. J.; Silverton, R. E. Introduction to medical laboratory technology. 7. ed. London: Butterworth Heinmann, 1998.

Baldrian, P.; Wiesche, C.; Gabriel, J.; Nerud, F.; Zadrazil, F. Influence of cadmium and mercury on activities of ligninolytic enzymes and degradation of polycyclic aromatic hydrocarbons by Pleurotus ostreatus in soil. Applied Environmental Microbiology, v. 66, no. 6, p. 2471-2478, 2000. https://doi.org/10.1128/aem.66.6.24712478.2000

Banso, A.; Adeyemo, S. O. Evaluation of antibacterial properties of tannins isolated 
from Dichrostachys cinerea. African Journal of Biotechnology, v. 6, no. 15, p. 1785-1787, 2007. https://doi.org/10.5897/AJB2007.000 $-2262$

Battestin, V.; Macedo, G.A. Tannase production by Paecilomyces variotii. Bioresources Technology, v. 98, no. 9, p.1832-1837, 2007. https://doi.org/ 10.1016/j.biortech.2006.06.031

Cheesbrough, M. District laboratory practices in tropical countries. 2. ed. London: Cambridge University Press, 2000. Part 2.

Chung, K. T.; Wong, T. Y.; Wei, C. I.; Huang, Y. W.; Lin, Y. Tannins and human health: A review. Food Science Nutrition, v. 38, no. 6, p. 421-464, 1998. https://doi.org/10.1080/ 10408699891274273

Cook, N. C.; Samman, S. Flavonoidschemistry, metabolism, cardioprotective effects and dietary sources. The Journal of Nutritional Biochemistry, v. 7, no. 2, p. 6676, 1996. https://doi.org/10.1016/S09552863(95)00168-9

Cordell, G. A.; Quinn-Beattie, M. L.; Farnsworth, N. R. The potential of alkaloids in drug discovery. Phytotherapy Research, v. 15 , no. 3, p. 183-205, 2001.

Ekpo, K. E.; Onigbinde, A. O. Nutritional potentials of larva of Rhynchophorus phoenicis (F). Pakistan Journal of Nutrition, v. 4, no. 5, p. 287-290, 2005. http://doi.org/ 10.3923/pjn.2005.287.290

Eleazu, C. O.; Iroaganachi, M. A.; Okoronkwo, J. 0. Determination of the physico-chemical composition, microbial quality and free radical scavenging activities of some commercially sold honey samples in Aba, Nigeria: 'The effect of varying colours'. International Journal of Biomedical Research, v. 3, no. 2, p. 1-7, 2013.

Ferreira, I. C. F. R.; Morales, P.; Barros, L. Wild plants, mushrooms and nuts: Functional food properties and applications. London: Wiley-Blackwell, 2017.

Gan, R.-Y.; Li, H.-B.; Gunaratne, A.; Sui, Z.-Q.; Corke, H. Effects of fermented edible seeds and their products on human health. Comprehensive Reviews in Food Science and Food Safety, v. 9, no. 4, p. 489-531, 2017. https://doi.org/10.1111/1541-4337. 12257
Giardina, P.; Faraco, V.; Pezzella, C.; Piscitelli, A.; Vanhulle, S.; Sannia, G. Laccases: A neverending story. Cellular and Molecular Life Sciences, v. 67, no. 3, p. 369-385, 2010. https://doi.org/10.1007/s00018-009-0169-1

Godfray, H. C. J.; Garnett, T. Food security and sustainable intensification. Philosophical Transactions of the Royal Society B: Biological Sciences, 369:20120273, 2014. https://doi.org/10.1098/rstb.2012.0273

Habtamu, F. G.; Negussie, R. Antinutritional factors in plant foods: Potential health benefits and adverse effects. International Journal of Nutrition and Food Sciences, v. 3, no. 4, p. 284-289, 2014. https://doi.org/ 10.1007/s13197-013-1242-1

Han, J. Solid-state fermentation of cornmeal with the basidiomycete Hericulum erinaceum for degrading starch and upgrading nutritional value. International Journal of Food Microbiology, v. 80, no. 1, p. 61-64, 2003. https://doi.org/10.1016/s0168-1605 (02)00122-8

Igyor, M. A.; Ikyo, S. M.; Gernah, D. I. The food potential of potato yam (Dioscorea bulbifera). Nigerian Food Journal, v. 22, p. 209-215, 2004.

Khalaf, M. A.; Meleigy, S. A. Reduction of free gossypol levels in cottonseed meal by microbial treatment. International Journal of Agriculture and Biology, v. 10, p. 185190, 2008.

Kubala J. Essential amino acids: Definition, benefits and food sources. 2018. Available from: <https://www.healthline.com/ nutrition/essential-amino-acids $>$. Accessed on: Apr. 23, 2019.

Kubátová, A.; Erbanová, P.; Eichlerova, I.; Homolka, L.; Nerud, F.; Sasek, V. PCB congener selective biodegradation by the white rot fungus Pleurotus ostreatus in contaminated soil. Chemosphere, v. 43, p. 207-215, 2001. https://doi.org/10.1016/ s0045-6535(00)00154-5

Kumar, S.; Mishra, A.; Pandey, A. K. Antioxidant mediated protective effect of Parthenium hysterophorus against oxidative damage using in vitro models. BMC Complementary and Alternative Medicine, 13:120, 2013. https://doi.org/10.1186/ 1472-6882-13-120 
Lavelli, V.; Cristina, P.; Francesca, G.; Monica, L.; Ella, P. Circular reuse of bio-resources: The role of Pleurotus spp. in the development of functional foods. Food Function, v. 9, no. 3, p. 1353-1372, 2018. https://doi.org/ $10.1039 / \mathrm{c} 7$ fo0 $1747 \mathrm{~b}$

Li, B.; Yongxia, L.; Quanxin, W.; Junjie, H.; Xiaoli, Y.; Heran, L.; Shaojuan, W.; Huaan, W.; Shaojie, L.; Hongwei, L. Nutritive and bioactive components in rice fermented with edible mushroom Pleurotus enrygii. Mycology, v. 4, no. 2, p. 96-102, 2013. https://doi.org/10.1080/21501203.2013.81 6386

Luz, J. M. R.; Paes, S. A.; Torres, D. P.; Nunes, M. D.; Silva, M. C. S.; Mantovani, H. C.; Kasuya, M. C. M. Production of edible mushroom and degradation of antinutritional factors in jatropha biodiesel residues. LWT - Food Science and Technology, v. 50, no. 2, p. 575580, 2013. https://doi.org/10.1016/ j.lwt.2012.08.006

Majcherczyk, A.; Johannes, C.; Hüttermann, A. Oxidation of polycyclic aromatic hydrocarbons (PAH) by laccase of Trametes versicolor. Enzyme and Microbial Technolology, v. 22, p. 335-341, 1998. https://doi.org/10.1016/S0141-0229(97) 00199-3

Mandalari, G.; Tomaino, A.; Arcoraci, T.; Martorana, M.; Turco, V. L.; Cacciola, F.; Rich, G. T.; Bisignano, C.; Saija, B.; Dugo, P.; Cross, K. L.; Parker, M.L.; Waldron, K. W.; Wickham, M. S. J. Characterization of polyphenols, lipids and dietary fibre from almond skins (Amygdalus communis L.). Journal of Food Composition and Analysis, v. 23, p. 166174, 2010. https://doi.org/10.1016/j.jfca. 2009.08.015

Mbome, I. L.; Agbor, E. T.; Treche, S. Digestibility and metabolism of flour from two yam species (D. dumetorum and $D$. rotundata) in school age children. Ecology of Food Nutrition, v. 34, no. 3, p. 217-225, 1995. https://doi.org/10.1080/03670244. 1995.9991462

Motomura, M.; Toyomasu, T.; Mizuno, K.; Shinozawa, T. Purification and characterization of an aflatoxin degradation enzyme from Pleurotus ostreatus. Microbiology Research, v. 158, no. 3, p. 237 242, 2003. https://doi.org/10.1078/09445013-00199
Nyanhongo, G. S.; Erlacher, A.; Schroeder, M.; Gubitz, G. M. Enzymatic immobilization of 2,4,6-trinitrotoluene (TNT) biodegradation products onto model humic substances. Enzyme and Microbial Technology, v. 39, no. 6, p. 1197-1204, 2006. https://doi.org/ 10.1016/j.enzmictec.2006.03.004

Obadoni, B. O.; Ochuko, P. O. Phytochemical studies and comparative efficacy of the crude extract of some homeostatic plants in Edo and Delta States of Nigeria. Global Journal for Pure Applied Sciences, v. 8, no. 2, p. 203-208, 2001. https://doi.org/10.4314/ gjpas.v8i2.16033

Okwu, D. E. Phytochemicals and vitamin content of indigenous species of South Eastern Nigeria. Journal of Sustainable Agricultural Environment, v. 6, p. 30-34, 2004.

Olatoye, K. K.; Arueya, G. L. Toxicological parameters of albino rats fed with extruded snacks from Aerial yam (Dioscoria bulbifera) and African breadfruit seed (Treculia africana). Food Science and Nutrition, v. 6, no. 1 , p. 94-100, 2018. https://doi.org/ $10.1002 /$ fsn 3.533

Princewill-Ogbonna, I. L.; Abagha, O. J.; Ijioma, S. N. Haematological and histopathological parameters of rats fed with aerial yam (Dioscorea bulbifera). Journal of Food Science and Technology Research, v. 2, no. 2, p. 9-16, 2015. https://doi.org/ $10.1002 /$ fsn3.533

Shriram, V.; Jahagirdar, S.; Latha, C.; Kumar, V.; Puranik, V. A potential plasmid-curing agent, 8-epidiosbulbin E acetate, from Dioscorea bulbifera L. against multidrugresistant bacteria. International Journal of Antimicrobial Agents, v. 32, no. 5, p. 405-410, 2008. https://doi.org/10.1016/ j.ijantimicag.2008.05.013

Stamets, P. Growth parameters for gourmet and medicinal mushroom species. In: Stamets, P. Growing gourmet and medicinal mushrooms. 3. ed. Berkeley: Ten Speed Press, 2000.

Stryer, L. Biosynthesis of amino acids and heme. In: Stryer, L. Biochemistry. 4. ed. New York: W. H. Freeman and Co., 1997. p. 717718.

Trease, G. E.; Evans, W. C. Phytochemicals. In: Trease, G. E.; Evans, W.C. (Ed.). 
Pharmacognosy. 15. ed. London: Saunders Publishers, 2002. p. 42-44.

Vasanthi, H. R.; Mukherjee, S.; Ray, D.; Pandian Jayachandran, K. S.; Lekli, I.; Das, D. K. Protective role of air potato (Dioscorea bulbifera) of yam family in myocardial ischemic reperfusion injury. Food Function, v. 1, no. 3, p. 278-283, 2010. https://doi.org/ $10.1039 / \mathrm{c0}$ fo00048e

Weng, X.-Y.; Sun, J.-Y. Kinetics of biodegradation of free gossypol by Candida tropicalis in solid-state fermentation. Biochemical. Engineering Journal, v. 32, no. 3, p. 226-232, 2006. https://doi.org/ 10.1016/j.bej.2006.10.007

Whitney, E.; Rolfes, S. R. Understanding nutrition. Wadsworth: Cengage, 2013.
Willett, W. C.; Koplan, J. P.; Nugent, R.; Dusenbury, C.; Puska, P.; Gaziano, T. A. Prevention of chronic disease by means of diet and lifestyle changes. In: Jamison, D. T.; Breman, J. G.; Measham, A. R.; Alleyne, G.; Claeson, M.; Evans, D. B.; Jha, P.; Mills, A.; Musgrove, $P$. Disease control priorities in developing countries. 2. ed. Washington: The World Bank; New York: Oxford University Press, 2006. 